\title{
VISUALIZATION TECHNOLOGIES FOR MATERIAL DEVELOPMENT IN PROFESSIONAL TRAINING OF FUTURE SPECIALISTS
}

\author{
Ganna Alieksieieva \\ Berdyansk State Pedagogical University \\ Shmidta Str. 4, Berdyansk, 71110, Ukraine \\ alekseeva@ukr.net, https://orcid.org/0000-0003-3204-3139 \\ Olga Novak \\ Hryhorii Skovoroda University in Pereiaslav \\ Sukhomlynski Str. 30, Pereiaslav, 08400, Ukraine \\ novakolyia@gmail.com, https://orcid.org/0000-0003-3187-1872 \\ Miziuk Viktoriia \\ Izmail State University of Humanities \\ Repin Str. 12, Izmail, 68601, Odessa region \\ miziviki@ukr.net,orcid.org/0000-0001-8291-6597 \\ Yuliia Saienko \\ Bohdan Khmelnytsky Melitopol State Pedagogical University \\ Hetmanska Str. 20, Melitopol, 72300, Ukraine \\ saenko.yulya@gmail.com, https://orcid.org/0000-0001-9174-7684
}

\begin{abstract}
The article presents the experience of using visualization technology in the professional training of future engineers-teachers of computer profile, in particular video lectures on the example of training IT specialists. It is emphasized that it is necessary to change the paradigm of teaching computer disciplines in the context of visualization of didactic materials as a basis for the abstraction of material. Practical aspects of the development of didactic and methodical materials of technology of students training for computer science' school course with the video materials used are considered. It is proved that a large number of different methods and tools of teaching is an effective mechanism that can solve both educational and methodological problems for the modern educational innovations' application in higher education, optimize the educational process and implement new approaches to lifelong learning. It is established that the use of e-learning systems with the implementation of visualization contributes to a more successful perception and memorization of educational material. This is due to the work intensification at the same time both hemispheres: the left hemisphere usually works in traditional learning, the right hemisphere, the responsibility for the image-emotional perception of the proposed information, is activated by visualization. As a result, there is a creative and professional development of personality. The classical methods of teaching the discipline "School course of informatics" with lecture-practical forms of teaching with text didactic materials that have a low level of abstraction compared to the use of video materials are analysed. It is proved that, due to the technical advantages of the use of video materials, the quality and efficiency of the educational process is improved. That is, visualization technologies have significant potential, which guarantees high-quality professional training of students.
\end{abstract}

Key words: higher education, professional training, future engineers-teachers, information technologies, content management systems, video materials. 
2021 Випуск/ Issue 48

\section{Г. М. Алєксєєва}

Бердянський державний педагогічний університет

вул. Шмідта, 4, м. Бердянськ, 71110, Україна

О. М. Новак

Університет Григорія Сковороди в Переяславі

вул. Сухомлинського, 30, м. Переяслав, 08400, Україна

В. А. Мізюк

Ізмаїльський державний гуманітарний університет

вул. Рєпіна, 12, м. Ізмаїл, 68601, Одеська область

Ю. О. Саєнко

Мелітопольський державний педагогічний університет імені Богдана Хмельницького

вул. Гетьманська, 20, м. Мелітополь, 72300, Україна

\section{ТЕХНОЛОГІЇ ВІЗУАЛІЗАЦІЇ ДЛЯ РОЗРОБКИ МАТЕРІАЛІВ У ПРОФЕСІЙНІЙ ПІДГОТОВЦІ МАЙБУТНІХ ФАХІВЦІВ}

У статті представлений досвід використання технології візуалізації у професійній підготовці майбутніх інженерів-педагогів комп'ютерного профілю, зокрема відео лекції на прикладі підготовки IT фахівців Бердянського державного педагогічного університету. Акцентується, що необхідна зміна парадигми викладання дисциплін комп'ютерного профілю в контексті візуалізації дидактичних матеріалів як основи абстрагування матеріалу. Розглядаються практичні аспекти розробки дидактичних та методичних матеріалів технології навчання студентів шкільному курсу інформатики з використанням відеоматеріалів. Доведено, що велика кількість різноманітних методів й інструментальних засобів навчання $€$ дієвим механізмом, здатним вирішити як навчально-методичні проблеми для застосування сучасних освітніх інновацій в вищій освіті, здійснити оптимізацію навчального процесу, а також реалізувати нові підходи до безперервного і випереджаючого навчання. Встановлено, що використання електронних навчальних систем із засобами візуалізації сприяють більш успішному сприйняттю і запам'ятовуванню навчального матеріалу студентами. Це обумовлено активізацією роботи одночасно обох півкуль: ліва півкуля звично працює при традиційній формі навчання, а права півкуля, відповідальна за образно-емоційне сприйняття пропонованої інформації, активізується при візуалізації. В результаті відбувається творчий і професійний розвиток особистості. Проаналізовано класичні методики навчання дисципліни “Шкільний курс інформатики“ з лекційно-практичними формами навчання з переважно текстовими дидактичними матеріалами, що мають низький рівень абстрагування порівняно з використанням відеоматеріалів. Доведено, що, завдяки технічним перевагам застосування відеоматеріалів здійснюється підвищення якості й ефективності освітнього процес. Тобто технології візуалізації мають значний потенціал, що гарантує якісну професійну підготовку студентів.

Ключові слова: вища освіта, професійна підготовка, майбутні інженери-педагоги, інформаційні технології, системи керування контентом, відеоматеріали.

\section{А. Н. Алексеева}

Бердянский государственный педагогический университет

ул. Шмидта, 4, г. Бердянск, 71110, Украина

О. М. Новак

Уноверситет Григороя Сковороды в Переяславе

ул. Сухомлинского, 30, г. Переяслав, 08400, Украина

В. А. Мизюк

Измаильский государственный гуманитарный университет ул. Репина, 12, г. Измаил, 68601, Одесская область

Ю. А. Саенко

Мелитопольский государственный педагогический университет имени Богдана Хмельницкого

ул. Гетьманская, 20, г. Мелитополь, 72300, Украина

\section{ТЕХНОЛОГИИ ВИЗУАЛИЗАЦИИ ДЛЯ РАЗРАБОТКИ МАТЕРИАЛОВ} В ПРОФЕССИОНАЛЬНОЙ ПОДГОТОВКЕ БУДУЩИХ СПЕЦИАЛИСТОВ

В статье представлен опыт использования технологии визуализации в профессиональной подготовке будущих инженеров-педагогов компьютерного профиля, в частности, видео-лекции на примере подготовки IT-специалистов Бердянского государственного педагогического университета. Акцентируется, что необходима смена парадигмы преподавания дисциплин компьютерного профиля в контексте визуализации дидактических материалов как основы абстрагирования материала. Рассматриваются практические аспекты разработки дидактических и методических материалов технологии обучения студентов школьному курсу информатики с использованием видеоматериалов. Доказано, что большое количество разнообразных методов и инструментальных средств обучения является действенным механизмом, способным решить учебно-методические проблемы для при- 
менения современных образовательных инноваций в высшем образовании, осуществить оптимизацию учебного процесса, а также реализовать новые подходы к непрерывному и опережающему обучению. Установлено, что использование электронных обучающих систем со средствами визуализации способствует более успешному восприятию и запоминанию учебного материала студентами. Это обусловлено активизацией работы одновременно обоих полушарий: левое полушарие обычно работает при традиционной форме обучения, а правое полушарие, отвечающее за образно-эмоциональное восприятие предлагаемой информации, активизируется при визуализации. В результате происходит творческое и профессиональное развитие личности. Проанализированы классические методики обучения дисциплине «Школьный курс информатики» с лекционно-практическими формами обучения с преимущественно текстовыми дидактическими материалами, имеющими низкий уровень абстрагирования по сравнению с использованием видеоматериалов. Доказано, что благодаря техническим преимуществам применения видеоматериалов осуществляется повышение качества и эффективности образовательного процесса. То есть технологии визуализации имеют значительный потенциал, что гарантирует качественную профессиональную подготовку студентов.

Ключевые слова: высшее образование, профессиональная подготовка, будущие инженеры-педагоги, информационные технологии, системы управления контентом, видеоматериалы.

Problem formulation. An urgent problem today is the need to change the paradigm of teaching computer science disciplines. A large number of technologies, methods, and tools lead to the need to use them in teaching disciplines of computer profile, where one of the main principles of teaching is a high level of abstraction of educational material. Classical methods of teaching students computer disciplines provide a lecture-practical form, which is overloaded with text didactic materials with a low level of abstraction. The use of video materials as a means of visualization technologies is relevant for the information support of disciplines [5]. That is, the development of scientifically sound methods of teaching students computer disciplines using video materials is relevant.

Analysis of basic research and publications. The issue of training future engineers-teachers in the conditions of education informatization is revealed in the works of Ukrainian researchers, where the conceptual principles of the informatization process of the education system are sufficiently covered: G. Alieksieieva [1-3], S. Hunko, Yu. Zhuk, B. Kindzer, H. Kindzer [8], A. Maiboroda, T. Nestorenko, A. Ostenda [18], I. Smyrnova, S. Tadiian, A. Trofymova; the problem of forming the engineers-teachers professional skills: N. Apatov, V. Bykov, L. Babenko, Yu. Doroshenko, A. Yershov, B. Zhytomyrskyi, N. Lazarev, A. Pikhota, S. Rakov and others scientists; problems of using Web-technologies in teaching: A. Aleksanian, Yu. Bykov, S. Voitovych, O. Zhuhastrov, P. Ivannikov, M.Spirin, V. Tryus and others researchers. Today methods of using visualization technologies in the teaching of disciplines "Content Management Systems" are in the process of formation. So, the study of their use in the training of future engineers-teachers is an urgent scientific and practical task.
The analysis of pedagogical literature, scientific research on the problem of introduction of visualization technologies in the process of teaching students in the educational process, and the experience of educational institutions show that for training it is necessary to accelerate the receipt and processing of educational information and focus on the general trend of individualization of the learning process.

That is, the problem of professional training of future engineers-teachers with the use of information and communication technologies, in particular for the development of video tutorials and videos becomes actual.

Works of Ya. Hlynskyi, V. Lazarenko, D. Tarasova, and D. Fedasiuk are devoted to the issues of theoretical substantiation, development and introduction of electronic educational video resources into the educational process. The analysis of these works showed that despite the high publishing activity on the training of students and the use of videos that reveal their technical component and justifies the economic and pedagogical feasibility of use, the problem of using video materials in the process of professional training of future engineers-teachers and determining the features and development of scientifically sound technology of teaching computer disciplines with the use of video materials is insufficiently studied.

The work aim is to shed light on the practical aspects of the development of didactic and methodological materials of technology for teaching students computer disciplines with the use of video materials in the process of professional training of computer students.

Presenting main material. In modern conditions of increasing social requirements for the level of professionalism and competitiveness of future professionals, questions to the modern sys- 
tem of higher education arise. In this regard, the search for new approaches to the modern educational process becomes an urgent and important pedagogical task. One of the alternative directions of its solution is to change the approach to the professional training of future engineers-teachers at a university in the context of teaching students to develop didactic and methodical materials of technology for teaching computer science using video [4].

Thus, modern world trends in the informatization of education are: the creation of a single educational space [5]; active introduction of new teaching aids and methods focused on the use of information technologies; synthesis of tools and methods of traditional and computer learning; creation of a system of advanced education; the emergence of a new direction of the teacher's activity - development of information technologies of teaching and program-methodical complexes; changing the content of the teacher's activity: from the "reproducer" of knowledge to the developer of new technology (which on the one hand, increases his creative activity, and on the other - requires a high level of technological and methodological training); formation of a system of lifelong learning as a universal form of activity aimed at the continuous development of personality throughout life [10]. Education informatization requires the introduction into higher education of innovative methods, tools and forms of training of future professionals of the new formation, the powerful information infrastructure creation in higher education institutions with developed information and computer learning environment, introduction of Internet technologies, e-learning, communication networks (global, national, local) $[6,9]$. In addition, computer technology in the educational process is an integral part of pedagogical technology and requires teachers to expand their training. Computer technology also allows to improve the students' education quality, taking into account their individual psychological and physiological characteristics [4].

Computer-based learning technologies make it possible to combine the processes of learning, consolidating and controlling educational material with the individualization of the learning process, reducing frontal types of work and increasing the share of individual group forms and methods of learning.

For this purpose, the use of information educational technologies in the field of education is spreading, which are based on using modern computer, interactive method: computer training programs, technical training based audio-video equipment, remote training, conferencing, and more [7].
For example, multimedia has an important place among the means of education in future professionals' training. Multimedia learning tools are a set of hardware and software that allow the user to communicate with a computer using a variety of natural environments: graphics, hypertext, sound, animation, video [10]. They provide the user with the following types of information: text; image; animated pictures; audio comments; digital video. Technologies that allow a computer to integrate, process, and simultaneously reproduce different types of signals, different environments, means, and methods of information exchange, are called multimedia [9].

Let's consider various ways of multimedia means an application in the educational process. It should be emphasized that the use of multimedia, including video materials in the educational process contributes to increasing student motivation to learn; realization of the social purpose, namely informatization of a society; intensification of the learning process; student personality development; development of skills of independent work with educational material; increasing the effectiveness of training through its individualization. The technical advantages of using video materials are speed, maneuverability, efficiency, the ability to view and listen to fragments and other multimedia functions; didactic - interactivity of classes (creating the effect of presence, a sense of authenticity, reality of events, interest, desire to learn and see more).

If we talk about the first type of classes, then this method involves the independent work of the teacher at all stages of preparation. The teacher must have a special program for recording video and be able to use it. Of course, now on the Internet you can find ready-made videos on certain topics, but they do not always correspond to a specific topic of the lesson. Video material can be given more widely than required at a certain stage of training or, conversely, only a small part of it is given. In this situation, the teacher has to adapt to the finished version of the video or create new learning material (video). Therefore, knowing the peculiarities of the group's success, it is best not to search for videos on the Internet, but to develop them. Despite the complexity and time spent on the preparation of materials, this type of work in the classroom justifies itself. An interesting supply of material promotes the growth of assimilation of the material. By watching videos, students are more actively involved in the learning process, and if they still have interactive tasks, then the process of perception of new information increases not only in students interested in the subject but also in the weaker. An- 
other distinctive feature of this method is the ability to practice this material by students themselves, in their absence in class: you can view the material at a convenient time and place, and in case of complications or questions, discuss them with the teacher. Also, this material can be viewed again at home by anyone, consolidating and working out the material. With the growth of information technology innovation, students can do so even with their cell phones, not to mention computers, laptops and tablets [12].

When conducting classes of the second type, the teacher only needs to select fragments of video that fit the semantic content of the lesson and the research material, that is, you do not need to create a video yourself. Then the teacher selects or develops the exercises and tasks that are performed by students before, in time and after watching the video. Exercises can be individual, with varying degrees of difficulty, providing individual and differentiated approaches to learning, group, which helps to develop socialization skills among peers and aimed at working with the whole group, when the competitive moment pushes students to participate more actively. The use of this type of lesson motivates students to study the material with its non-standard approach to its presentation, students' interest in the lesson increases, they remember more, emotional comfort is felt in the lesson.

The use of video materials in lectures forms the student's ability to convert oral and written information into a visual form, highlighting the most significant and essential elements [13]. The lecture is reduced to a coherent detailed commentary by the teacher of the prepared visual aids $[9,14]$.

Thus, even though the use of video materials is only a fragment of the lesson, during which students receive this or that information via digital media, learn to perceive it, and apply it in practice, the use of video materials increases interest in studying the subject and allows qualitatively increase the level of professional training of future specialists.

We will describe in more detail the learning experience, in particular the practical aspects of developing didactic and methodological materials of technology for teaching students computer skills using video materials in the process of training computer students of Berdyansk State Pedagogical University.

The purpose of using videos in the training of future IT professionals is improving the quality of education by intensifying the learning process, individualization and differentiation, intensification of student work; implementation of such pedagogical principles as scientific and accessible, system- atic and consistent, individual, differentiated, personality-oriented approach $[14,18]$.

Achieving the above goal will be based on the implementation of a principles system. All principles are closely linked and form a single system designed to ensure the goals achievement. At the same time, we can identify the principles that play a leading role in the use of video materials in the training of engineers-teachers. It should be noted that the principles system allows the inclusion of new principles and rethinking existing ones. Let us dwell in detail on the principles that are most important for the use of video materials in the training of engineers-teachers [13], [15].

The learning individualization principle implies that the assimilation of educational material, the pace of mastering it, the strength and awareness of knowledge depend not only on the activities of the teacher, but also on the cognitive abilities and abilities of students due to many factors, including perception, memory, thinking activities, physical development.

The clarity principle is the computer visualization of educational information.

The accessibility principle is the need to match the content, methods, and forms of education to the characteristics of students and their level of development. Among the main provisions of this principle are the following: the need to match the pace of information communication by the teacher and the speed of assimilation of this information by students; orientation of students, first of all, on an understanding of the researched material, instead of on memorization; movement "from simple to complex", "from near to far", "from easy to difficult", "from unknown to known", etc.

The redundancy principle implies a knowingly excessive number of tasks that cannot be performed only at a certain time. Redundancy is a necessary condition for the organization of educational activities in the classroom, which has a different level of preparation for the subject: depending on the level of preparedness of the student, the teacher has the opportunity to offer him tasks of a certain level of complexity. Also, redundancy provides the teacher with additional tasks that can be recommended to students for independent work. However, a significant part of the tasks must be completed by all students.

The feedback principle implies a mandatory reaction to the actions of the student in various types of educational activities (for example, correcting mistakes, announcing answer options, etc.).

The interactivity principle is one of the leading ones. It is the interaction of two or more parties. 
Interaction takes place with the help of information and communication technologies and involves communication between several communicators. Real communication is carried out through forms of telecommunications (e-mail, chat, forum, Skype) and on the platforms of social services (blogs, wikis, podcasts, etc.) [16].

The consciousness principle is one of the leading didactic principles implemented in the classroom. The implementation of this principle in education means a conscious attitude of students to the learning process itself, which involves mastering the techniques of independent work [17].

The consciousness principle is one of the leading didactic principles implemented in the classroom. The implementation of this principle in education means a conscious attitude of students to the learning process itself, which involves mastering the techniques of independent work.

The activity principle involves the linguistic activity of students in the learning process, which means the intensity of mental processes in the student's activities related to attention, thinking, memory. The main sources of activity are goals, motives, desires, and interests. To support them, various teaching methods are used, including problem-solving tasks, visual aids. Knowledge, skills, and abilities are formed in the process of active mental work of students [19].

The outlined methodological principles reflect different aspects of the educational process and have different areas of application. The choice of a form of student education depends on the didactic purpose, the content of educational material, as well as the level of pedagogical culture of the teacher, and the state of the educational and methodological base of the university. In turn, the education organization form determines the choice of didactic methods [11].

Let's consider the main forms of organization of the educational process using video materials. Lecture is methodological and organizational basis for all classes, including independent ones (methodological, because it introduces the student to science in general, provides the course conceptual; organizational - because other forms of classes are somehow "tied" to the lecture, often logically planned after it, based on it meaningfully and thematically). Its main didactic purpose is the formation of an oriented theoretical basis for further mastering of educational material by students. It serves to explain a difficult and complex topic; its typical features are the introduction and characterization of new concepts, disclosure and detailing of the material, the conclusions of the teacher, answers to questions (these are the points that we will use in the video). This is a theoretical form of learning, the main method oral, consistent presentation of content. The lecture is characterized by a large amount of educational material, fundamentality, the complexity of logical constructions, proofs, and generalizations. On it, students receive installation and a direction for further independent work [9].

On the example of studying the discipline "School course of informatics" from our experience was chosen a lecture with the use of video materials, which can be both classical and problematic. In the classical form of the lecture, video materials can be used to activate the goals, motives, desires, and interests of students. When conducting a problem lecture with the help of video materials, students are invited to reflect and answer problem problems. The method of problem statement activates students, promotes the development of analytical thinking.

We will reveal the practical aspect of our study. You don't have to have a camcorder to create videos today, just use the free computer software available on the Internet. The process of their creation consists of the following stages: search, collection, and preparation of materials for the creation of video material; program selection; video structuring (Fig. 1) [4].

Today, there are many special devices to capture video from the screen. The competition of such programs in the software market encourages developers to improve and simplify their products. Therefore, the use of such programs does not involve any difficulties and does not require special knowledge from the user. The choice of tools for creating videos depends solely on the concept of convenience and capabilities of the computer system. Another important component of the software choice is the feasibility of using paid versions. Of course, software products that are distributed for free may have some limitations, such as limited video recording time, fixed file size, inability to change the video format, and others. But among the free programs, you can find the option that can best meet your needs.

The free Bandicam program was chosen to study the course "School course of informatics". This is a compact screen recording program for Windows that can record everything that happens on the PC screen in high quality video format. Also, we can record a specific part of the screen or demonstrate certain actions using DirectX / OpenGL / Vulkan graphics technology. Bandicam will help to record video with a high compression ratio while maintaining close to the original quality and providing higher performance compared to other recording programs with similar functions. 

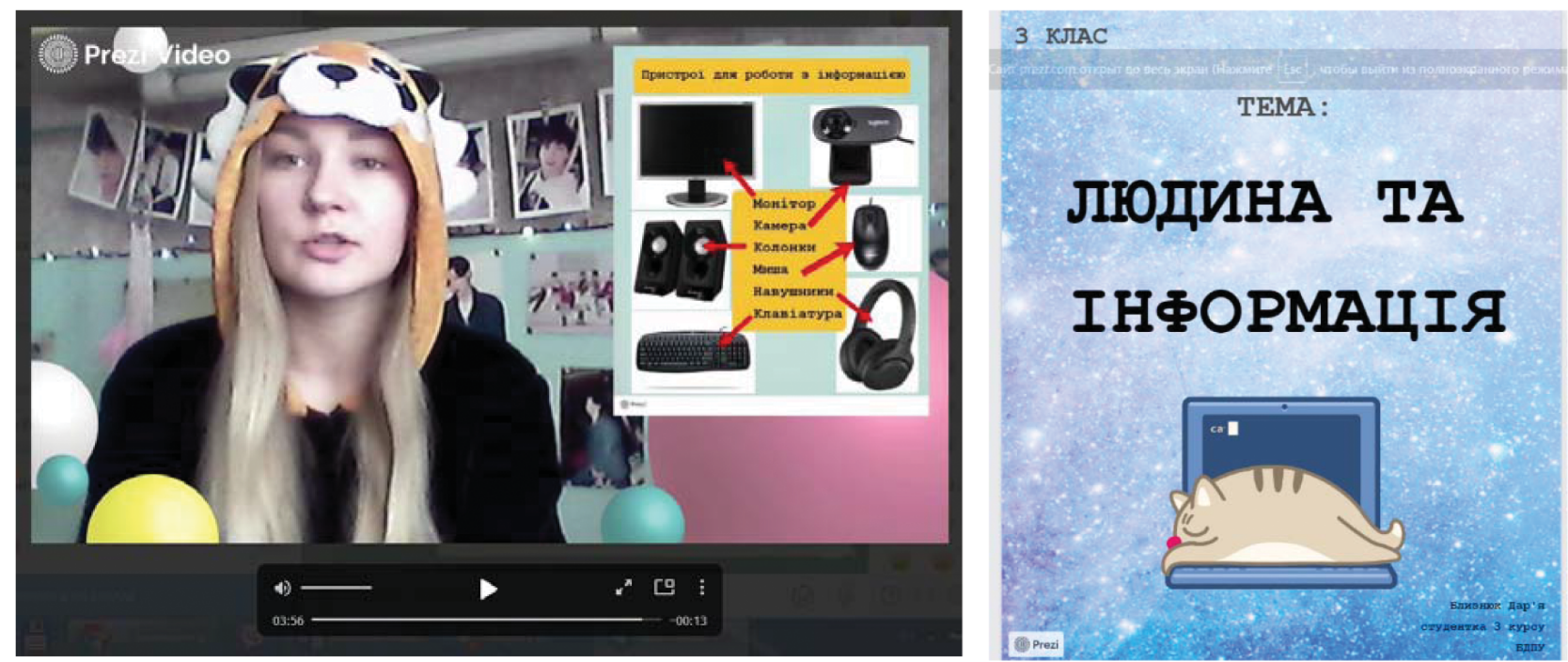

Fig. 1. The fragment of a video lecture on the course "School course of informatics" by means of Prezi

Let's prescribe the stages of video content development.

1. Development of topics and preparation of a Word document.

2. Creating a presentation with Prezi for the development of didactic and methodological materials.

3. Creating a video presentation using Prezi Design and Prezi Video.

4. Using Bandicam to develop methodological materials.

The purpose of the course "School course of informatics" is to study the teaching of school course of informatics in secondary schools and to acquaint students with modern trends in teaching informatics. And the study of technologies for creating, maintaining websites in the form of video screensavers or entire videos on various topics, which demonstrate the stages of work in Prezi Design, Prezi Video, and Bandicam after the first viewing allows students to quickly create their videos using the latest technologies.

Each video lasts from five to fifteen minutes and is accompanied by text and audio material (Fig. 2). All videos developed by students are saved by the program automatically and can be used via links on the Internet to place them on websites (https://prezi.com/i/tqiwgl4ujwuf/presentation/).

The developed videos can be used when students study the discipline "School course of informatics" both for demonstration directly in the classroom, and for consolidation of the studied material and self-study of the program Prezi, Bandicam.

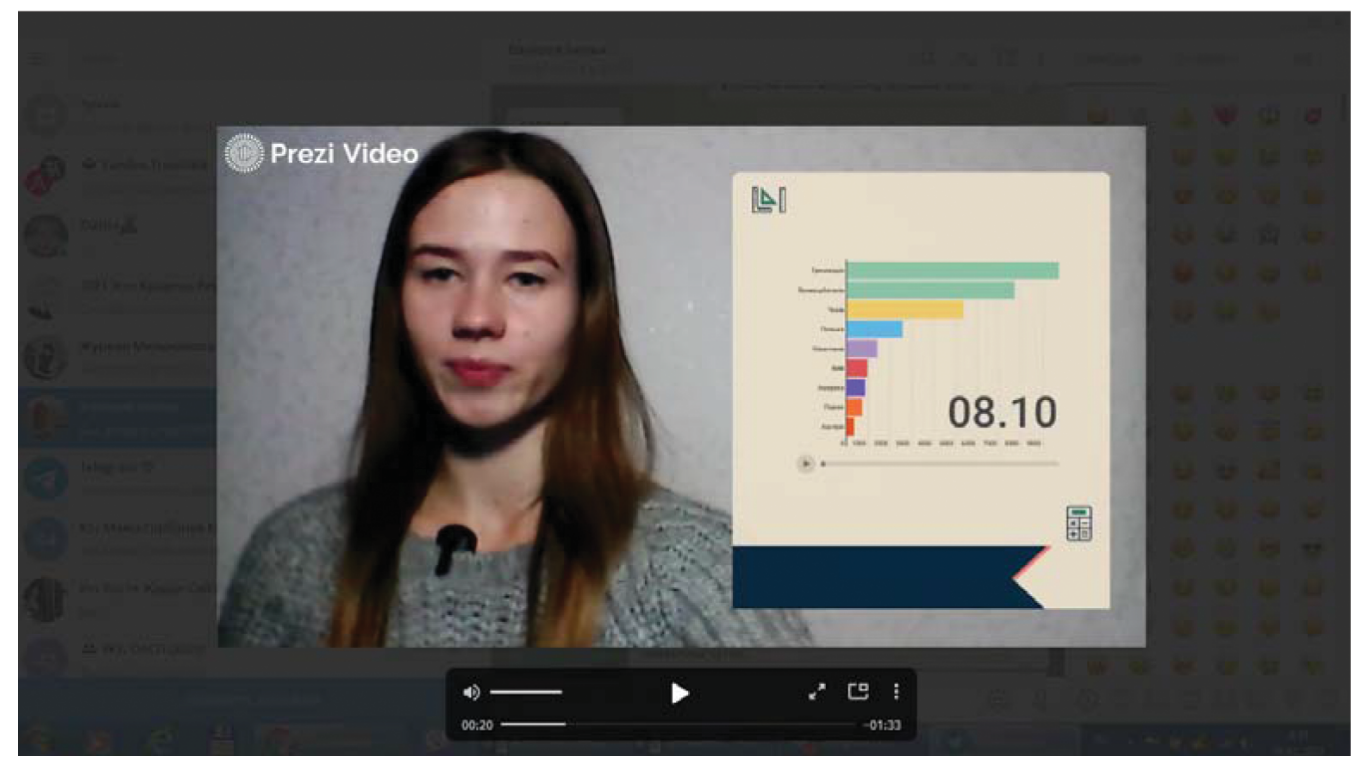

Fig. 2. The fragment of a video lecture with methodical materials 
Conclusions from this study and prospects for further exploration in this direction. Reorientation of traditional education to a fundamentally new education is associated with the creative development of the individual, with a change in the role of the student, where she becomes an active participant in the educational process. Psychological and pedagogical research shows that the use of e-learning systems with visualization tools contributes to a more successful perception and memorization of educational material. This is due to the activation of both hemispheres at the same time: the left hemisphere usually works in the traditional form of learning, and the right hemisphere, responsible for the image and emotional perception of the proposed information, is activated during visualization. The result is the creative and professional development of the individual.

The developed videos together with classical teaching methods improve the education quality and provide additional emotional and intellectual incentives for education in the training of future engineers-teachers on the example of the discipline "School course of informatics" students of Berdyansk State Pedagogical University. Also, these technologies are planned to use for education of future specialists at Hryhorii Skovoroda University in Pereiaslav and Bohdan Khmelnytsky Melitopol State Pedagogical University,

\section{СПИСОК ВИКОРИСТАНИХ ДЖЕРЕЛ ТА ЛІТЕРАТУРИ:}

1. Алєксєєва Г.М. Формування готовності майбутніх соціальних педагогів до застосування комп'ютерних технологій у професійній діяльності. Монографія. Донецьк: ЛАНДОН-ХХІ, 2014. 269 с.

2. Алєксєєва Г.М., Бабич П.М. Використання платформи Arduino для професійної підготовки майбутніх інженерів-педагогів. Физико-математическое образование. 2018. №. 4 (18). С. 12-17. https: //doi. org/10.31110/2413-1571-2018-018-4-002

3. Алєксєєва Г.М. Використання інформаційно-комунікаційних технологій в процесі професійної підготовки студентів педагогічних вузів. Актуальні питання природничо-математичної освіти. Суми, Україна: ВВП «Мрія», 2014, С.184-191.

4. Глазунова О.Г. 3 досвіду застосування графічно-інформаційних технологій для організації навчальнопізнавальної діяльності студентів. Інформаційний вісник Навчально-методичного центру по підготовці молодших спеціалістів Міністерства аграрної політики України. Київ: НМЦ. № 35, 2002. С. 33-37.

5. Джеджула О.М. Теорія і методика графічної підготовки студентів інженерних спеціальностей вищих навчальних закладів: автореф. дис... д-ра пед. наук: 13.00.04. Тернопіль, 2007. 42 с.

6. Жигірь B.I. Методологічні підходи як основа науково-педагогічних досліджень у професійній освіті. Педагогіка формування творчої особистості у вищій і загальноосвітній школах. 2016. №48. С. $107-115$.

7. Сосницька Н.Л. Теоретико-методичні засади фахової підготовки вчителів фізики та математики в умовах освітнього інформаційного середовища : монографія /Н.Л. Сослицька, О.В. Школа, В.В. Ачкан та ін.; за заг. ред. Н.Л. Сосницької. Донецьк : Ландон-XXI, 2012. 241 с.

8. Кіндзер Б.М., Кіндзер Г.Б. Використання сучасних комп'ютерних та цифрових технологій у навчальній (тренерській), викладацькій та змагальній діяльності в східних одноборствах (на прикладі кіокушин карате). Теорія та методика фізичного виховання. 2007. Вип.8. С.41-44.

9. Кривильова О., Сосницька Н., Олексенко К. Проектування навчального середовища - професійна задача майбутніх учителів початкової школи. Вища освіта України в контексті цивілізаційних змін та викликів: стан, проблеми, перспективи розвитку: [кол. моногр.] / [Калінічева Г.І. (кер. авт. кол., наук. ред.), Заліток Л.М., Любовець О.М. та ін.; за заг. ред. Г.І. Калінічевої]; ЗВО «Міжнародний науково-технічний університет імені академіка Юрія Бугая». Київ: Фенікс, 2020. С. 272-290.

10. Нищак І.Д. Методична система навчання інженерно-графічних дисциплін майбутніх учителів технологій. Вісник Глухівського національного педагогічного університету імені Олександра Довженка. Сер.: Педагогічні науки. 2016. Вип. 30. С. 23-29.

11. Нищак І.Д., Моштук В.В. Комп'ютерна графіка. Навч. посібник для вищих педагогічних навчальних закладів. Дрогобич: РВВ ДДПУ ім. І. Франка, 2007, 352 с.

12. Ожга М. М. Проблеми графічної підготовки майбутніх інженерів-педагогів у наукових дослідженнях, Проблеми інженерно-педагогічної освіти. 2012. №. 34-35., С. 226-233.

13. Alieksieieva H., Antonenko O., Ovsyanikov, O., \& Matviichuk-Yudina, O. The using of modern internet messengers in the process of teaching engineering and pedagogical direction students. Youth and market. 2019 . №5 (184). C.52-56. https://doi.org/10.24919/2308-4634.2020.215170

14. Kravchenko N.V., Alyeksyeyeva H.M., Gorbatyuk L.V. Curriculum Optimization by the Criteria of Maximizing Professional Value and the Connection Coefficient of Educational Elements, Using Software Tools: (ICTERI 
2018: 14th International conference on ICT in education, research, and industrial applications] [Електронний pecypc] (Kyiv, Ukraine, May 14-17, 2018). CEUR Workshop Proceedings, 2018, Vol.1. Pp. 365-378.

15. Lavrik V., Cortez L., Alekseeva A., García G. T., Juarez P. G., Poblano J. Development of the CAD system for designing non-standard constructions from elastomers. Development, International Journal of Innovative Research in Science, Engineering and Technology. Vol 3, Issue 3, March. 2014. Pp. 10717-10726.

16. Liu Z. Research on the Curriculum System Construction Plan for Animation Design and Production of Specialty in High Vocational Colleges. 2nd International Conference on Social Science and Technology Education (ICSSTE 2016). Atlantis Press, 2016.

17. Fedorov A. Media educational practices in teacher training. 2010. Acta Didactica Napocensia. N 3, Vol.3. Pp.57-70.

18. Ostenda A., Nestorenko T., Ostenda J. Practical education on a higher level in Poland: example of Katowice School of Technology. Наукові записки Бердянського державного педагогічного університету. Серія : Педагогічні науки : зб. наук. пр. 2018. Вип.1. С.186-190.

19. Park S. Reviewing Educational Methodology in the Domain of Animation at the Smart Media Era. TECHART: Journal of Arts and Imaging Science. 2015. T. 2, №. 4. C. 32-37.

\section{REFERENCES:}

1. Alyeksyeyeva, H.M. (2014). Formuvannia hotovnosti maibutnikh sotsialnykh pedahohiv do zastosuvannia kompiuternykh tekhnolohii u profesiinii diialnosti [Formation of readiness of future social educators to use computer technologies in professional activity], Monohrafiya. Donetsk: LANDON, 269. (in Ukrainian).

2. Alyeksyeyeva, H.M. \& Babych, P.M. (2018). Vykorystannia platformy Arduino dlia profesiinoi pidhotovky maibutnikh inzheneriv-pedahohiv [Use the Arduino platform for the professional training of future engineer educators], Fizyko-matematychna osvita, no (18), pp. 12-17. https: //doi.org/10.31110/2413-1571-2018-0184-002. (in Ukrainian).

3. Alyeksyeyeva, H.M. (2014). Vykorystannia informatsiino-komunikatsiinykh tekhnolohii v protsesi profesiinoi pidhotovky studentiv pedahohichnykh vuziv [Victorious information-communal technologies in the process of professional training of students of pedagogical universities]. Aktual'ni pytannya pryrodnycho-matematychnoyi osvity. Sumy, Ukrayina: VVP «Mriya», pp.184-191. (in Ukrainian).

4. Glazunova, O.G. (2003). Metodyka navchannia maibutnikh fakhivtsiv ahrarnoho profiliu zasobamy kompiuternoi hrafiky [Methodology of training future specialists of agrarian profile by means of computer graphics]. K.yiv: NAU, № 35, pp. 33-37. (in Ukrainian).

5. Dzhedzhula, O.M. (2007). Teoriia i metodyka hrafichnoi pidhotovky studentiv inzhenernykh spetsialnostei vyshchykh navchalnykh zakladiv [Theory and methodology graphically ï preparation of students of engineering specialties of different schools]. avtoref. dys. d-ra ped. nauk: 13.00.04 Ternopil's'kyy natsional'nyy pedahohichnyy universytet imeni Volodymyra Hnatyuka. Ternopil, 42. (in Ukrainian).

6. Zhyhir, V.I. (2016). Methodological approaches as a basis of scientific and pedagogical research in vocational education. Pedahohika formuvannia tvorchoi osobystosti u vyshchii i zahalnoosvitnii shkolakh, (48), pp.107-115 (in Ukrainian).

7. Sosnytska, N.L., Shkola, O.V., Achkan, V.V., Voloshyna, A.K., Kirieieva I.V., \& Yatsenko, O.S. (2012). Theoretical and methodological principles of professional training of teachers of physics and mathematics in the educational information environment: monohrafiia. Donetsk: LANDON.

8. Kindzer, B.M., Kindzer, H.B. Vykorystannia suchasnych kompiuternych ta tsyfrovych tekhnolohii u navchalnii (trenerskii), vykladatskii ta zmahalnii diialnosti v skhidnylh odnoborstvakh (na prykladi kiokushyn karate). Teoriia ta metodyka fizychnogo vykhovannia. 2007. Vol.8. pp.41-44. (in Ukrainian).

9. Kryvylova, O.A., Sosnytska, N., Oleksenko, K. (2020). Designing a learning environment is a professional task for future primary school teachers. Higher education in Ukraine in the context of civilizational changes and challenges: state, problems, prospects: [kol. monohr.] ZVO «Mizhnarodnyi naukovo-tekhnichnyi universytet imeni akademika Yuriia Buhaia». Kyiv: Feniks, pp. 272-290.

10. Nyshchak, I.D. (2016). Metodychna systema navchannia inzhenerno-hrafichnykh dystsyplin maibutnikh uchyteliv tekhnolohii [Methodology of training future specialists of agrarian profile by means of computer graphics]. Visnyk Hlukhivskoho natsionalnoho pedahohichnoho universytetu imeni Oleksandra Dovzhenka. Ser. : Pedahohichni nauky.Vyp. 30. pp. 23-29. (in Ukrainian).

11. Nyshchak, I.D. \& Moshtuk V.V. (2007). Kompiuterna hrafika. [Computer Graphics]. Navch. posibnyk dlya vyshchykh pedahohichnykh navchal'nykh zakladiv. Drohobych: RVV DDPU im. I.Franka. (in Ukrainian).

12. Ozhha, M.M. (2012). Problemy hrafichnoi pidhotovky maibutnikh inzheneriv-pedahohiv u naukovykh doslidzhenniakh [Problems of graphic training of future engineers-teachers in scientific researches], Problemy inzhenerno-pedahohichnoyi osvity. №. 34-35, pp. 226-233. (in Ukrainian). 
2021 Випуск/ Issue 48

13. Alieksieieva, H., Antonenko 0., Ovsyanikov 0., \& Matviichuk-Yudina O. (2020). The using of modern internet messengers in the process of teaching engineering and pedagogical direction students. Molod' $i$ rynok: Naukovopedahohichny zhurnal. Drohobych: Drohobychskyi derzhavnyi pedahohichnyi universytet imeni I. Franka. 2019. №5(184), zhovten’ 2020, C.52-56. https://doi.org/10.24919/2308-4634.2020.215170/ (in English).

14. Kravchenko, N.V. Alyeksyeyeva H.M. Gorbatyuk L.V.(2018). Curriculum Optimization by the Criteria of Maximizing Professional Value and the Connection Coefficient of Educational Elements, Using Software Tools: (ICTERI 2018: 14th International conference on ICT in education, research, and industrial applications). Kyiv, Ukraine, May 1417, 2018. CEUR Workshop Proceedings, no.1, pp. 365-378. (in English).

15. Lavrik V., Cortez L., Alekseeva A., García G.T., Juarez P.G. Poblano J. (2014). Development of the CAD system for designing non-standard constructions from elastomers. Development, no. 3(3), pp 80-91. (in English).

16. Liu Z. (2016). Research on the Curriculum System Construction Plan for Animation Design and Production of Specialty in High Vocational Colleges. 2nd International Conference on Social Science and Technology Education (ICSSTE 2016). Atlantis Press. (in English).

17. Fedorov, A. (2015). Media educational practices in teacher training. Acta Didactica Napocensia. 3, Vol.3, pp.5770. (in English).

18. Ostenda, A., Nestorenko T., Ostenda J. (2018). Practical education on a higher level in Poland: example of Katowice School of Technology. Naukovi zapysky Berdyanskoho derzhavnogo pedahohichneho universytetu. Seriia: Pedahohichni nauky : zb. nauk. prac. Vol.1. BDPU, pp.186-190. (in English).

19. Park, S. (2015). Reviewing Educational Methodology in the Domain of Animation at the Smart Media Era. TECHART: Journal of Arts and Imaging Science. №. 2(4), pp. 32-37. (in English). 